\title{
Business Strategies for Managing the Legal Risks of Social Media
}

\author{
Evan A. Peterson ${ }^{1}$ \\ ${ }^{1}$ College of Business Administration, University of Detroit Mercy, Detroit, MI, USA \\ Correspondence: Evan A. Peterson, College of Business Administration, University of Detroit Mercy, Detroit, MI, \\ USA. Tel: 1-313-993-1114. E-mail: petersea@udmercy.edu
}

Received: May 20, 2014

Accepted: June 9, 2014 Online Published: August 29, 2014

doi:10.5539/jms.v4n3p96

URL: http://dx.doi.org/10.5539/jms.v4n3p96

\begin{abstract}
The recent growth of social media has dramatically changed interactions between the personal, business, and legal spheres of society. Corporations now use social networks, blogs, and even virtual worlds for marketing, recruiting, customer service and brand management purposes. Moreover, through the establishment of corporate pages, companies can reap increased web exposure, traffic, and popularity, while acquiring valuable insight into consumer perceptions. Despite the multitude of tangible benefits provided by social media, organizations are now beginning to recognize the legal and business risks that accompany these opportunities. Legal scholars and practitioners are increasingly examining the effects of social media on organizational strategy, with particular attention being paid to social media's involvement in the struggle between the negligent hiring theory and anti-discrimination laws. Although social media policies and employee training have been proposed as methodologies to address the legal costs associated with this conflict, these legal-centric approaches largely fail to examine the issue from a comprehensive strategy-oriented perspective. Accordingly, in this paper I will contribute to the academic literature by outlining how organizations can manage litigation costs derived from social media activities through the use of best practices and risk analysis.
\end{abstract}

Keywords: best practices, business law, discrimination law, social media, negligent hiring theory

\section{Introduction}

The meteoric rise of social media in recent years has radically altered the relationship between the personal, business, and legal spheres of society. As of September 2013, Facebook boasted 1.19 billion monthly active users (Facebook, 2013), with over 20\% logging in at least five times a day (Honigman, 2012). LinkedIn, publicized as the world's largest professional network, has over 230 million members spanning over 200 countries (LinkedIn, 2013). Since the birth of Twitter, users have sent over 160 billion tweets (Honigman, 2012). In light of the increased market presence wrought by the ever growing number of social media outlets, companies are recognizing the critical necessity of a solid social media presence.

Firms now use social networks, blogs, and even virtual worlds for a multitude of tasks, including marketing, recruiting, customer service and brand management. Through the establishment of corporate pages, companies can reap increased web exposure, traffic, and popularity, while gaining valuable insight into consumer perceptions of products and services. A 2011 study by Burson-Marsteller revealed that, of the Fortune Global 100: 77\% had Twitter accounts, $61 \%$ had Facebook fan pages, 57\% had YouTube channels, and 36\% had corporate blogs (Delaney, 2012). Despite the benefits provided by social media, organizations are concurrently beginning to recognize that such opportunities are accompanied by abundant legal and business risks (Delaney, 2012; Naito, 2012). For example, Federal Trade Commission guidelines can render companies liable for unsubstantiated online statements about products or services, even if such statements are made without authorization (Business Counselor Update, 2012). Equally significant concerns exist in the areas of intellectual property, defamation, and labor relations. Moreover, organizations are also bearing witness to public relations nightmares that can result through the viral aspects of social media. A 2009 YouTube video depicting Domino's employees allegedly violating multiple health codes while making sandwiches for delivery, received more than a million hits in only a few days (Clifford, 2009; Sprague, 2011).

Due to the developing nature of the law (Bagley, 2010), an emerging area of legal research examines social media's involvement in the costly and puzzling struggle between negligent hiring theory and anti-discrimination laws. In brief, case law on negligent hiring theory suggests that if employers fail to conduct online searches prior 
to hiring job applicants, and those searches would have exposed the candidates'dangerous tendencies, then employers can be held liable if the employees later injure someone. Paradoxically, employers that guard against negligent hiring liability by conducting a pre-employment online search risk potential exposure to liability for employment discrimination when hiring decisions are based, in whole or in part, on protected-class information (Smedinghoff, 2011; Sprague, 2011). As noted by Peebles (2012), "Pre-employment Internet screening thus presents a Catch-22 for diligent employers: a hiring official who fails to conduct these investigations breaches the duty to search, but an employer that makes use of online information increases the likelihood that a snubbed prospective employee can successfully bring a host of other lawsuits."

In response to this apparent legal paradox, scholars have argued that properly crafted and instituted social media policies will mitigate the likelihood and costs of litigation derived from allegations of discrimination in connection with social media investigations (Sprague, 2011; Peebles, 2012; Bannister, Gabel, \& Ulrich, 2013). However, the failure of existing scholarship to examine the costs and consequences of this issue, beyond mere discussions of social media policy implementation, is especially problematic. Although social media policies may reduce the likelihood of litigation, exaggerated corporate reliance on their effectiveness is misplaced. Litigation is inevitable. Building upon the work of Siedel and Haapio (2011) and others, in this paper I will contribute to existing academic literature by outlining how organizations can minimize the unavoidable costs of litigation derived from social media by streamlining litigation management through the use of best practices and risk analysis.

\section{Negligent Hiring Theory and Pre-Employment Internet Screening}

Human resource departments have been utilizing Google, Bing, and other common search engines for years (Bell, 2011; Bannister, Gabel, \& Ulrich, 2013) to investigate if particular aspects of an applicant's lifestyle may be problematic or contrary to company values (Finder, 2006). In 2010, a survey commissioned by Microsoft revealed that nearly $80 \%$ of hiring professionals conduct online research of an applicant (Sprague, 2011). With the growth of social networking websites, employers can take a personalized look into an applicant's background, lifestyle, and attitude (Sprague, 2011).

At first glance, this may appear to be a groundbreaking victory for human resource departments. However, apart from traditional management concerns related to the selection of suitable company personnel (Piotrowski \& Armstrong, 2006), a new array of legal issues is presented by an organizations' use of social media investigation. In addition to privacy (Sprague, 2008), labor relations (Stine, 2010) and wage concerns (Business Counselor Update, 2012), employers now face added anxieties over potential liability arising under the negligent hiring theory. Negligent hiring theory is derived from the tort of negligence: if individuals engage in an activity, they have a duty to use reasonable care in performing those activities (Peebles, 2012). In order to exercise reasonable care in the employment setting, employers must investigate whether hiring a person for a particular job will create a risk of harm to others (Ponticas v. K.M.S. Invs., 1983). As the court indicated in Ponticas (1983), negligent hiring liability is "predicated on the negligence of an employer in placing a person with known propensities, or propensities which should have been discovered by reasonable investigation, in an employment position in which, because of the circumstances of the employment, it should have been foreseeable that the hired individual posed a threat of injury to others." Foreseeability is central to liability under negligent hiring theory. For example, in Coffey v. City of New York (2008), the facts demonstrated that although the city was aware of a corrections officer's history of alcoholism, the only visible consequence was lateness and absenteeism. After reviewing available evidence, the court found no liability under negligent hiring theory, holding it unforeseeable that the officer would drive while under the influence of alcohol.

As noted by Peebles (2012), given the connection between foreseeability and reasonable investigation in negligent hiring theory, there is ample justification behind the growing concern that failure to conduct proper online screening can expose organizations to negligent hiring liability (Elzweig \& Peeples, 2009). Case law has consistently demonstrated that negligent hiring imposes a duty upon employers to inspect the backgrounds of job applicants through appropriate means (Saine v. Comcast Cablevision of Ark., Inc., 2003; Munroe v. Universal Health Servs., Inc., 2004). Cases examining the use (or misuse) of social media in the context of negligent hiring have not yet been litigated. However, established precedent strongly suggests that organizations that fail to scrutinize job applicants through social media will be liable if germane evidence of an employee's dangerous tendencies could have been uncovered through a reasonable internet search (Smedinghoff, 2011; Sprague, 2011; Peebles, 2012). 


\section{Discrimination and the Legal Hazards of Social Media Screening}

By undertaking the due diligence necessary to satisfy the negligent hiring theory, organizations simultaneously risk exposure to liability for discrimination under an extensive patchwork of local, state, and federal laws. Under Title VII of the Civil Rights Act, the cornerstone of federal employment discrimination law, it is unlawful for an employer to discriminate based on an applicant's membership in a protected class, including on the grounds of race, color, religion, sex or national origin (42 U.S.C. § 2000e-2(a)(1), 2006). In conjunction with this statute, organizations are prohibited from asking any questions that may lead to the discovery of protected information during the application or interview process. Prohibited topics include questions related to marital status, religious observance, child care, or ancestry (EEOC Guide, 2014). An employment decision cannot be based on protected class information, regardless of whether the information is voluntarily offered by the applicants or obtained through a reasonable search of the applicants' social media profiles (Bannister, Gabel, \& Ulrich, 2013). For example, employers that view applicants' Facebook profiles may discover a variety of protected information, including facts related to religion, national origin, or marital status. If any such information is taken into consideration when making a hiring decision, liability for unlawful discrimination may result (Peebles, 2012). Furthermore, liability may arise even when discriminatory intent does not exist. For example, employer practices of systematically discounting applicants that like "gangsta rap" on Facebook may disproportionally affect African American men (Bannister, Gabel, \& Ulrich, 2013), and consequently form the basis for discrimination lawsuits under Title VII.

\section{Can Social Media Policies Address the Conflict between Negligent Hiring Theory and Title VII?}

The legal conundrum created by pre-employment social media screening presents a Catch-22 even for well-intentioned organizations. On one hand, companies that fail to conduct a sufficient investigation into an applicant's background, one that includes a review of her social media activities, risk liability under the negligent hiring theory. On the other hand, organizations that intentionally consider or unintentionally review an applicant's protected information face potential litigation for unlawful discrimination (Peebles, 2012). In order to reduce the threat of litigation, it has been suggested that organizations defer social media investigations to non-decision makers (Conway, 2013) and keep detailed records of all social media searches (Reicher, 2013). However, a substantial portion of existing research has argued that employers may mitigate potential liability by implementing social media policies that oversee the online screening of job applicants (Sprague, 2011; Peebles, 2012; Bannister, Gabel, \& Ulrich, 2013). For a more detailed description of the contents and coverage of social media policies used in conjunction with hiring decisions, see Conway (2013).

According to recent case statistics, 96 of every 100 discrimination plaintiffs, exclusive of dismissals and settlements, will ultimately be unsuccessful (Hannaford, 2008; Eyer, 2012). Nevertheless, organizations must not be misled by these illusory figures. Although social media policies may reduce the likelihood of litigation or assist corporate defendants in achieving favorable outcomes, no company is litigation proof. Direct evidence of discrimination is not necessary in order for a plaintiff to institute litigation, as plaintiffs are only required to articulate sufficient facts in support of plausible claims of discrimination (Bell Atl. Corp. v. Twombly). The ability of plaintiffs to institute litigation without direct evidence of discrimination has significant implications for organizations. Given that massive legal fees can begin accruing in the defense of adversarial litigation the moment a case is filed, it is no secret that the transaction costs of litigation alone are a substantial price of doing business in the United States (Gill, Santos, \& Kessel, 2014). Increases in the cost of legal services have surpassed increases in the consumer price index for many years (United States Bureau of Labor Statistics, 2013). Fortune 200 companies reported spending between $\$ 1.6$ million- $\$ 2$ million in litigation costs per case, even in cases where the amount in controversy did not exceed \$250,000 (Litigation Cost Survey, 2010). Between 2000 and 2008, average annual litigation costs as a percent of revenues increased $78 \%$ for 14 of the survey respondents (Litigation Cost Survey, 2010). Moreover, attorneys' fees for prevailing defendants in Title VII litigation are largely unattainable, absent evidence that the underlying lawsuits were vexatious, frivolous, or otherwise without merit (Clay, 2011; Employment Discrimination Law and Litigation, 2013). Exaggerated corporate reliance on social media policies is simply not cost effective. Consequently, a more comprehensive, strategy-oriented solution to social media litigation management is needed.

\section{Solving the Puzzle: Litigation Management, Best Practices and Risk Analysis}

Given the competitive edge that can accrue through well-organized and imaginative oversight of legal resources, organizations are beginning to regularly incorporate legal considerations into the strategic planning process (Oliver \& Holzinger, 2008; Ostas, 2009). In the face of ongoing changes to the complexity and breadth of governmental regulation (Siedel \& Haapio, 2011), organizations continue to confront the daunting task of 
managing increasing legal costs. Given the mysterious and convoluted nature of the law (Bagley, 2008; Altman, 2001; Arthur \& Shaw, 2006), legal departments have traditionally been regarded as cost centers within the overall corporate setting. However, such a mindset prevents organizations from seizing the full competitive potential of opportunities presented by their legal resources (Siedel \& Haapio, 2011). As noted by Gill, Santos and Kessel (2014), "Litigation cost reduction is a product of hundreds, even thousands, of decisions and good practices involving energy, teamwork, organization, corporate culture, technology, relationships, presentation skills, and various subsets of each of these actions." Building upon the work of Siedel and Haapio (2011) and others, the author contends that organizations can minimize the unavoidable costs of litigation by streamlining litigation management through the use of best practices and risk analysis. Due to the infancy of case law examining the relationship between social media, discrimination, and negligent hiring, organizations employ such measures to address the shortcomings of social media policies will be in a superior competitive position.

\subsection{Best Practices}

The DuPont Legal Model is an excellent illustration of the potential bottom line benefits when legal departments use best practices developed in other areas of the company (Siedel \& Haapio, 2011). Originally developed by DuPont attorneys to cut legal expenses and manage a caseload with an annual growth rate of $20-40 \%$ (Siedel \& Haapio, 2011), the Model was inspired by the business practices of the company's procurement department. Application of "business discipline" to the practice of law is evidenced by its tenets: knowledge of the value in applying business principles to legal practice; recognition of the power in strategic partnering; appreciation for the competitive edge afforded by a collaborative culture, and the effective utilization of information technology (DuPont, 2014a). Articulated benefits of the DuPont Legal Model include cost reduction, increased productivity and quality, augmented access to opportunities, and strengthened relationships among employees, law firms, and service providers (DuPont, 2014b). Moreover, to enable continuous integration of new strategies into the Legal Model, DuPont has further applied the Six Sigma methodology to support the law department's delivery of legal services. Through this application, DuPont's Legal Six Sigma supports adherence to cost control strategies, the management of corporate legal risks, and process excellence in core legal processes (DuPont, 2014c). The strategic value of DuPont's innovative approach is reflected in the numbers. During the first few years of the Model's implementation, DuPont's legal department was able to reduce legal expenses by $\$ 70$ million, cut the existing caseload in half, and diminish cycle time by over one year. By taking a business-focused, results-oriented approach to law, the DuPont Legal Model is an example of how corporate law departments can use best practices to improve the cost, quality, and efficiency of legal services.

\subsection{Risk Analysis}

Apart from adding value by adopting best practices used in other areas of the company, legal departments have also begun incorporating the use of risk analysis into departmental processes and procedures. As noted by Glidden, Lea, and Victor (2014), risk analysis must be viewed as a "best practice" in today's business environment. By providing a systematic, quantitative analysis of uncertainty in decision making, in-house counsel may utilize risk analysis to take a graphical, mathematical, and well-structured approach to litigation, thereby increasing the likelihood of an optimum result (Glidden, Lea, \& Victor, 2014). In addition, by using risk analysis to quantify the risks, benefits, and costs of litigation, legal departments will be positioned to become key contributors in the overall quest to add corporate value (Glidden, Lea, \& Victor, 2014).

Organizations that utilize formal risk analysis techniques have witnessed noticeable improvements in overall litigation results. For example, the litigation management process developed by ConocoPhillips utilizes a combination of reliable management practices, alternative dispute resolution, and aggressive litigation to achieve cost-effective litigation solutions in accordance with company business objectives (ConocoPhillips, 2014; Glidden, Lea, \& Victor, 2014). The process includes development of a case plan, creation of a quarterly case budget, and collection of vital information for use in litigation risk assessment and analysis. Within 90 days, a formal decision tree analysis is carried out, expected value calculations are made, and settlement recommendations are given when applicable (Glidden, Lea, \& Victor, 2014). Prior to adoption of the process, ConocoPhillips had no formal procedure for managing its litigation. Cases were given off-the-cuff evaluations, and no attempts were made to preserve ideas and strategies for use in future litigation. As a result, litigation results were unpredictable and unreliable (Glidden, Lea, \& Victor, 2014). Post-implementation, the quantitative risk analysis methodology and other components of the litigation management process have assisted ConocoPhillips in achieving success in tort, employment and commercial litigation (Glidden, Lea, \& Victor, 2014). In addition to increasing shareholder value, the company's systematic approach to litigation management has earned it a special reputation in the business community, leading one commentator to note, "ConocoPhillips has set a successful benchmark against which all companies' legal departments should be measured" (CPR Institute, 2007). 


\section{Conclusion}

The technological developments of recent years have forced U.S. organizations, lawmakers, and the general public to reevaluate their respective beliefs and assumptions related to the benefits and drawbacks of social media. Due to the increased burden placed upon employers to only hire safe employees, organizations are also experiencing a concurrent obligation not to use any uncovered information for discriminatory purposes. The end result is an ongoing skirmish between the negligent hiring theory and anti-discrimination laws. Although previous research has examined the risks and benefits associated with investigating the social media activities of job applicants, proposed solutions have largely failed to address this issue from a more comprehensive, strategy-oriented perspective. Therefore, in order to more efficiently address the legal costs that will occur despite the best social media policies, organizations must approach the issue from a business-oriented perspective and incorporate best practices and risk analysis into existing litigation management strategies. Areas for future research may include advanced studies involving the statistical analysis of the frequency, duration, and unintended financial effects of social media litigation.

\section{References}

Altman, A. (2001). Arguing About Law (2nd ed.). Belmont, CA: Wadsworth Publishing Company.

Arthur, J., \& Shaw, W. (2006). Readings in the Philosophy of Law (4th ed.). Upper Saddle River, NJ: Prentice-Hall.

Bagley, C. (2005). Winning Legally: How to Use the Law to Create Value, Marshall Resources, and Manage Risk. Boston, MA: Harvard Business School Press.

Bannister, M., Gabel, A., \& Ulrich, D. (2013). Employer Use of Facebook and Other Social Media in Hiring. Journal of the Kansas Bar Association, 82, 21-34.

Bell, M. (2011). Online Exploits Can Derail Hiring. The Washington Post, July 17, at T05.

Business Counselor Update. (2012). Social Media Policies and Procedures, (6).

Clifford, S. (2009). Video Prank at Domino's Taints Brand. N.Y. Times, Apr. 16, at B1.

Coffey v. City of New York. (2008). 49 A.D.3d 449, 853 N.Y.S.2d 551.

ConocoPhillips. (2014). Form 10-Q. from http://investing.businessweek.com/research/stocks/financials/drawFiling.asp?docKey=137-0001193125141 83842-4K1FI6OA9U6UICSR1MT6U3UCR3\&docFormat=HTM\&formType=10-Q

Conway, A. E. (2013). (Un)Friended: Using Social Media in Hiring and Firing Decisions. Association of Corporate Counsel Docket, 31(3), 27-38.

CPR Institute. (2007). ConocoPhillips, General Counsel Gates Receives CPR's 2007 Corporate Leadership Award. Retrieved from http://www.cpradr.org/Portals/0/Resources/Press\%20Releases/2007\%20Corporate\%20Leadership\%20Awar d\%20Press\%20Release.pdf

Delaney, J. (2012). Friending, Tagging and Tweeting: Social Media Overview. Practising Law Institute, 1077, 47-79.

DuPont. (2014a). 20 $0^{\text {th }}$ Anniversary. Retrieved from http://www.dupontlegalmodel.com/initiatives/20-years/

DuPont. (2014b). About DuPont. Retrieved http://www.dupontlegalmodel.com/initiatives/about-the-dupont-legal-model/

DuPont. (2014c). Six Sigma. Retrieved from http://www.dupontlegalmodel.com/initiatives/six-sigma/2014

Elzweig, B., \& Peeples, D. K. (2009). Using social networking web sites in hiring and retention decisions. SAM Advanced Management Journal, 74(4), 27.

Employment Discrimination Law and Litigation. (2013). Prevailing Defendants.

Equal Employment Opportunity Commission. EEOC Guide to Pre-Employment Questions. Retrieved from http://bos.ocgov.com/hr/hrportal/docs/docs_recruit_market/docs_selection/EEO\%20Guidelines\%20for\%20 Pre-Employment $\% 20$ Questions.pdf

Eyer, K. R. (2012). That's not Discrimination: American Beliefs and the Limits of Anti-Discrimination Law. Minnesota Law Review, 96, 1276-1361.

Facebook. (2013). Key Facts. Retrieved from https://newsroom.fb.com/Key-Facts 
Finder, A. (2006). When a Risque Online Persona Undermines a Chance for a Job. N.Y. Times, June 11, at 1.

Gabel, J. T. A., \& Mansfield, N. R. (2002). The Information Revolution and Its Impact on the Employment Relationship: An Analysis of the Cyberspace Workplace. American Business Law Journal, 40(2), 301-354. http://dx.doi.org/10.1111/j.1744-1714.2002.tb00848.x

Gill, C. D., Santos, J. A., \& Kessel, B. L. (2014). Pre-Litigation Management and Avoidance. Successful Partnering Between Inside and Outside Counsel.

Glidden, C. B., Lea, C. W., \& Victor, M. B. (2014). Evaluating Legal Risks and Costs with Decision Tree Analysis. Successful Partnering Between Inside and Outside Counsel.

Hannaford, K. W. (2008). Uncertain Justice: Litigating Claims of Employment Discrimination in the Contemporary U.S. Retrieved from http://www.americanbarfoundation.org/uploads/cms/documents/rlspring08.pdf

Honigman, B. (2012). 100 Fascinating Social Media Statistics and Figures from 2012. Huffington Post. Retrieved http://www.huffingtonpost.com/brian-honigman/100-fascinating-social-me_b_2185281.html

LinkedIn. (2013). AboutLinkedin. Retrieved from http://press.linkedin.com/about

Litigation Cost Survey of Major Companies. (2010). Retrieved from http://www.uscourts.gov/uscourts/RulesAndPolicies/rules/Duke\%20Materials/Library/Litigation\%20Cost\% 20Survey\%20of\%20Major\%20Companies.pdf

Munroe v. Universal Health Servs. Inc. (2004). 596 S.E.2d 604, 608

Naito, A. (2012). A Fourth Amendment Status Update: Applying Constitutional Privacy Protection to Employees' Social Media Use. University of Pennsylvania Journal of Constitutional Law, 14, 849-883.

Oliver, C., \& Holzinger, I. (2008). The Effectiveness of Strategic Political Management: A Dynamic Capabilities Framework. Academy of Management Review, 33(2), 496-520. http://dx.doi.org/10.5465/amr

Ostas, D. T. (2009). Legal Loopholes and Underenforced Laws: Examining the Ethical Dimensions of Corporate $\begin{array}{lllll}\text { Legal Strategy. American Business Law Journal, 46(4), 487-529. } & \text {. }\end{array}$ http://dx.doi.org/10.1111/j.1744-1714.2009.01084.x

Peebles, K. A. (2012). Negligent Hiring and the Information Age: How State Legislatures can Save Employers from Inevitable Liability. William and Mary Law Review, 53, 1398-1433.

Piotrowski, C., \& Armstrong, T. (2006). Current Recruitment and Selection Practices: A National Survey of Fortune 1000 Firms. North American Journal of Psychology, 8(3), 489-496.

Ponticas v. K.M.S. Invs. (1983). 331 N.W.2d 907, 911

Reicher, A. (2013). The Background of our Being: Internet Background Checks in the Hiring Process. Berkeley Technology Law Journal, 28, 115-153.

Saine v. Comcast Cablevision of Ark., Inc. (2003). 126 S.W.3d 339, 345

Siedel, G., \& Haapio, H. (2011). Proactive Law for Managers: A Hidden Source of Competitive Advantage. Burlington, VT: Gower Publishing Company.

Smedinghoff, T. (2011). Social Media: Issues for Business. Practising Law Institute Corporate Law and Practice Course Handbook Series, 1910, 529-540.

Sprague, R. (2008). Rethinking Information Privacy in an Age of Online Transparency. Hofstra Labor \& Employment Law Journal, 25, 397-398.

Sprague, R. (2011). Invasion of the Social Networks: Blurring the Line between Personal Life and the Employment Relationship. University of Louisville Law Review, 50(1), 1-34.

Title VII of the Civil Rights Act. (2006). 42 U.S.C. § 2000e-2(a)(1)

United States Bureau of Labor Statistics. (2013). Consumer Price Index, at Table 7.

\section{Copyrights}

Copyright for this article is retained by the author(s), with first publication rights granted to the journal.

This is an open-access article distributed under the terms and conditions of the Creative Commons Attribution license (http://creativecommons.org/licenses/by/3.0/). 